\title{
Effect of organic fertilization on productivity of some newly introduced basil varieties under Siwa Oasis conditions
}

\author{
Wael Ismail Mohamed Toaima, Moustafa Yehia Mohemed Ali Badawy, Emad Saleh Hamed* \\ Medicinal and Aromatic Plants Department, Desert Research Center, Cairo, Egypt.
}

\begin{tabular}{l}
\hline ARTICLE INFO \\
\hline Article history: \\
Received on: July 31,2021 \\
Accepted on: September 31, 2021 \\
Available online: February 15, 2022 \\
\hline
\end{tabular}

Key words:

Siwa Oasis, basil, compost

manure, foreign varieties, yield

\begin{abstract}
A split-plot design field trial was carried out on Ocimum basilicum L. plants at Siwa Oasis, Egypt, during the 2018 and 2019 seasons to study the effect of organic fertilization, cultivation of some foreign varieties, and their combination on yield. The main plots included applying two compost manure levels before planting (24 and $48 \mathrm{~m}^{3} /$ hectare). Subplots included cultivating five basil varieties (local and four foreign varieties: lime basil, smuglyanka basil, purple basil, and purple ruffles basil). The results revealed that applying compost manure at the highest level significantly increased herb and oil yield attributes over the lowest level. The evaluation of varieties showed that the purple ruffles and purple varieties were the most tolerant to abiotic stresses and recorded the significantly maximum herbage and oil yield. The essential oil chemical composition was affected by the interaction within treatments and harvest time. Applying $48 \mathrm{~m}^{3}$ compost/hectare and cultivation of foreign purple variety should be recommended in this region to produce the best yield quantity and quality characteristics (oil of high linalool of $50.95 \%-75.01 \%$ and minimum estragole of $0.00 \%-0.02 \%$, as well as attractive flavor and color) which could promote exports.
\end{abstract}

\section{INTRODUCTION}

Sweet basil (Ocimum basilicum L., family: Lamiaceae) is a valuable spice and medicinal and aromatic crop cultivated in many countries worldwide. The global statistics of basil production are quite difficult to get. Nevertheless, the top three exporter countries in the global basil market are China, India, and Germany. China is ranked 1 st with the share in export of $27.25 \%$, whereas it is ranked 7 th with the import of $3.42 \%$. India is ranked 2 nd with a stake in the export of $11.38 \%$, and it is ranked 6th through the import share by $3.49 \%$. Germany is ranked 3rd with the export percentage of $6.96 \%$, while it is ranked 2 nd with the stake in import of $12.08 \%$. Egypt is ranked 4th with a share in export of $4.54 \%$, and it is ranked 42 nd with an import percentage of $0.26 \%$ [1].

In Egypt, basil is cultivated on a wide scale compared to other medicinal and aromatic plants. The country's production is 7,000 tons with very little consumption inside. The area of basil farms is

\footnotetext{
*Corresponding Author

Emad Saleh Hamed, Medicinal and Aromatic Plants Department,

Desert Research Center, Cairo, Egypt.

E-mail:dr.emad128@yahoo.com
}

nearly 3,078 hectares, and the majority of production is for export, where shipping markets are expanding from the Europe to the USA and neighboring countries. The local rich flavor variety is currently farmed and exported to outside markets with Egyptian basil's brand name. However, introducing foreign varieties for cultivation in the country relying on world market demand and richness in other famous flavors is also considered important for growing trade [2-5]. Some of the favorable foreign varieties are (i) lime basil, (ii) smuglyanka basil, (iii) purple basil, and (iv) purple ruffles basil [6-8].

Nowadays, basil planting is extended to newly reclaimed lands through the Egyptian desert for increasing production and improving quality. One of the surest methods for growing basil under the harsh environs of newly reclaimed lands is adding adequate organic nutrition to ensure high quality. Different organic amendments can improve physical and chemical soil properties besides increasing soil microbial activity. It favors plant growth and provides a slow and steady supply of nutrients for plants as nutrients are bound in organic molecules that require the ongoing action of soil microbes to release them [9-15]. It is also essential to determine the most suitable varieties for each region according to its climatic conditions. The genus Ocimum is characterized by 
significant morphological and chemical composition variability [16].

Siwa Oasis in the Western Desert of Egypt (about $50 \mathrm{~km}$ East of the Libyan border) in the Sahara Desert represents promised and newly reclaimed lands for the cultivation of many medicinal and aromatic plants. The current research gap is that there is no available information on Siwa Oasis farmers concerning optimal amounts of organic fertilizers they should apply to basil plants and the best basil varieties they should cultivate. As a result, this study objective investigates the effect of manure additive and evaluates the cultivation of some foreign varieties to compare with local basil and their combination to reach the highest productive characteristics under this region's condition.

\section{MATERIALS AND METHODS}

This field trial was carried out during the two successive seasons of 2018 and 2019 in the Experimental Farm of the Desert Research Center at Khamisa Village $\left(29.21^{\circ} \mathrm{N}\right.$ and $\left.25.40^{\circ} \mathrm{E}\right)$, Siwa Oasis, Egypt [17]. The farm's soil and irrigation water analyses are presented in Table 1. Also, the meteorological data of Siwa Oasis are presented in Table 2.

The investigation layout was a split-plot design as the main plots included adding two compost manure levels before planting (24 $\mathrm{m}^{3} /$ hectare as recommended dose [18-20] and $48 \mathrm{~m}^{3} /$ hectare). At the same time, the subplots involved cultivating five basil varieties (local basil and four foreign varieties: lime basil, smuglyanka basil, purple basil, and purple ruffles basil) (Fig. 1). The seeds of lime and purple ruffles were obtained from Burpee Seeds Company, USA. The seeds of smuglyanka and purple varieties were obtained from SeDeK and Gavrish Seeds Companies, Moscow. The source of local basil seeds was obtained from the Egyptian Ministry of Agriculture and Land Reclamation. Compost manure was added to the sandy soil through soil preparation; the analysis of compost manure is shown in Table 1. The used organic fertilizer was made from a plant source. The laboratory analyses of soil, water, and compost manure samples were carried out as described by $[21,22]$.

Seeds were sown in the nursery on 15 March; seedlings were transplanted in the field on 1 May for both seasons. Cultivation was achieved under a drip irrigation system in rows $75 \mathrm{~cm}$ apart and $30 \mathrm{~cm}$ within hills as one seedling per hill. All agricultural practices were conducted as stated by the Egyptian Ministry of Agriculture and Land Reclamation [23]. The herbage was harvested at flowering three times per season on 12 July (first cut) and 15 September (second cut) as well as on 17 December (third cut). Least significant difference (LSD) test at 0.05 was used to compare the average means of treatments [24].

The following data were collected at each harvest time.

\subsection{Growth and Yield Parameters}

Plant height $(\mathrm{cm})$, fresh herb yield (ton/hectare), and dry herb yield (ton/hectare) were assessed.

\subsection{Essential Oil}

\subsubsection{Essential oil percentage}

The essential oil percentage was estimated using a Clevenger apparatus for the air-dried herb by hydrodistillation [25].

\subsubsection{Essential oil yield per hectare (l)}

This was calculated as follows: essential oil yield per plant $x$ number of plants/hectare.

\subsubsection{Essential oil chemical constituents}

Essential oil samples of the second season were analyzed using gas chromatography-mass spectrometry instrument stands at the Laboratory of Medicinal and Aromatic Plants, National Research Center, Egypt, with the following specifications: device: a Trace

Table 1: Analyses of soil, irrigation water of the experimental farm, and compost manure.

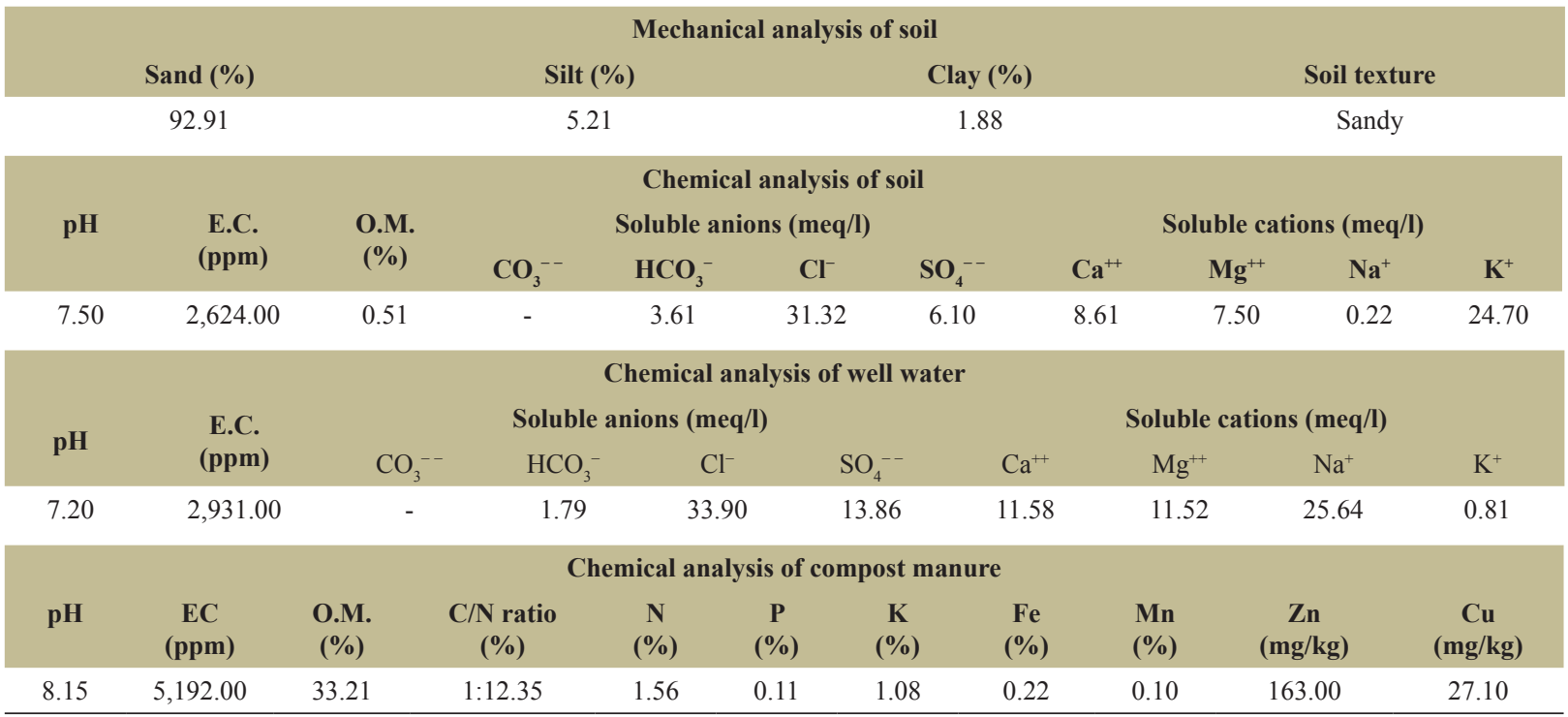


Table 2: Means of the meteorological data of Siwa Oasis during the seasons of 2018 and 2019.

\begin{tabular}{|c|c|c|c|c|c|c|c|}
\hline \multirow{2}{*}{\multicolumn{2}{|c|}{ Month }} & \multicolumn{3}{|c|}{ Air temperature $\left({ }^{\circ} \mathrm{C}\right)$} & \multirow{2}{*}{$\begin{array}{l}\text { Humidity } \\
\text { (\%) }\end{array}$} & \multirow{2}{*}{$\begin{array}{l}\text { Precipitation } \\
\text { (mm) }\end{array}$} & \multirow{2}{*}{$\begin{array}{c}\text { Wind } \\
(\mathrm{km} / \text { hour })\end{array}$} \\
\hline & & Maximum & Minimum & Average & & & \\
\hline \multirow[t]{4}{*}{ Winter season } & 22 to 31 December & 19.20 & 10.00 & 14.60 & 65.00 & 0.00 & 15.33 \\
\hline & January & 21.00 & 7.00 & 14.00 & 53.50 & 1.50 & 21.24 \\
\hline & February & 25.50 & 7.00 & 16.25 & 50.50 & 2.10 & 17.98 \\
\hline & 1 to 19 March & 31.00 & 8.50 & 19.75 & 38.70 & 0.20 & 19.85 \\
\hline Mean & & 24.18 & 8.13 & 16.15 & 51.93 & 0.95 & 18.60 \\
\hline \multirow[t]{4}{*}{ Spring season } & 20 to 31 March & 30.00 & 9.00 & 19.50 & 46.33 & 0.00 & 23.23 \\
\hline & April & 34.50 & 10.00 & 22.25 & 47.50 & 0.00 & 18.99 \\
\hline & May & 41.50 & 13.50 & 27.50 & 34.50 & 0.00 & 17.82 \\
\hline & 1 to 20 June & 33.00 & 18.50 & 25.75 & 35.19 & 0.00 & 19.58 \\
\hline Mean & & 34.75 & 12.75 & 23.75 & 40.88 & 0.00 & 19.91 \\
\hline \multirow[t]{4}{*}{ Summer season } & 21 to 30 June & 38.00 & 21.00 & 29.50 & 38.01 & 0.00 & 14.45 \\
\hline & July & 39.00 & 23.00 & 31.00 & 42.00 & 0.00 & 18.73 \\
\hline & August & 42.00 & 24.00 & 33.00 & 42.50 & 0.00 & 16.34 \\
\hline & 1 to 22 September & 38.00 & 22.00 & 30.00 & 50.93 & 0.00 & 19.31 \\
\hline Mean & & 39.25 & 22.50 & 30.88 & 43.36 & 0.00 & 17.21 \\
\hline \multirow[t]{4}{*}{ Autumn season } & 23 to 30 September & 34.00 & 19.00 & 26.50 & 46.57 & 0.00 & 13.89 \\
\hline & October & 32.50 & 14.50 & 23.50 & 48.50 & 0.00 & 18.34 \\
\hline & November & 28.50 & 11.00 & 19.75 & 49.00 & 0.00 & 18.44 \\
\hline & 1 to 21 December & 24.00 & 6.00 & 15.00 & 58.34 & 0.00 & 25.11 \\
\hline Mean & & 29.75 & 12.63 & 21.19 & 50.60 & 0.00 & 18.95 \\
\hline
\end{tabular}

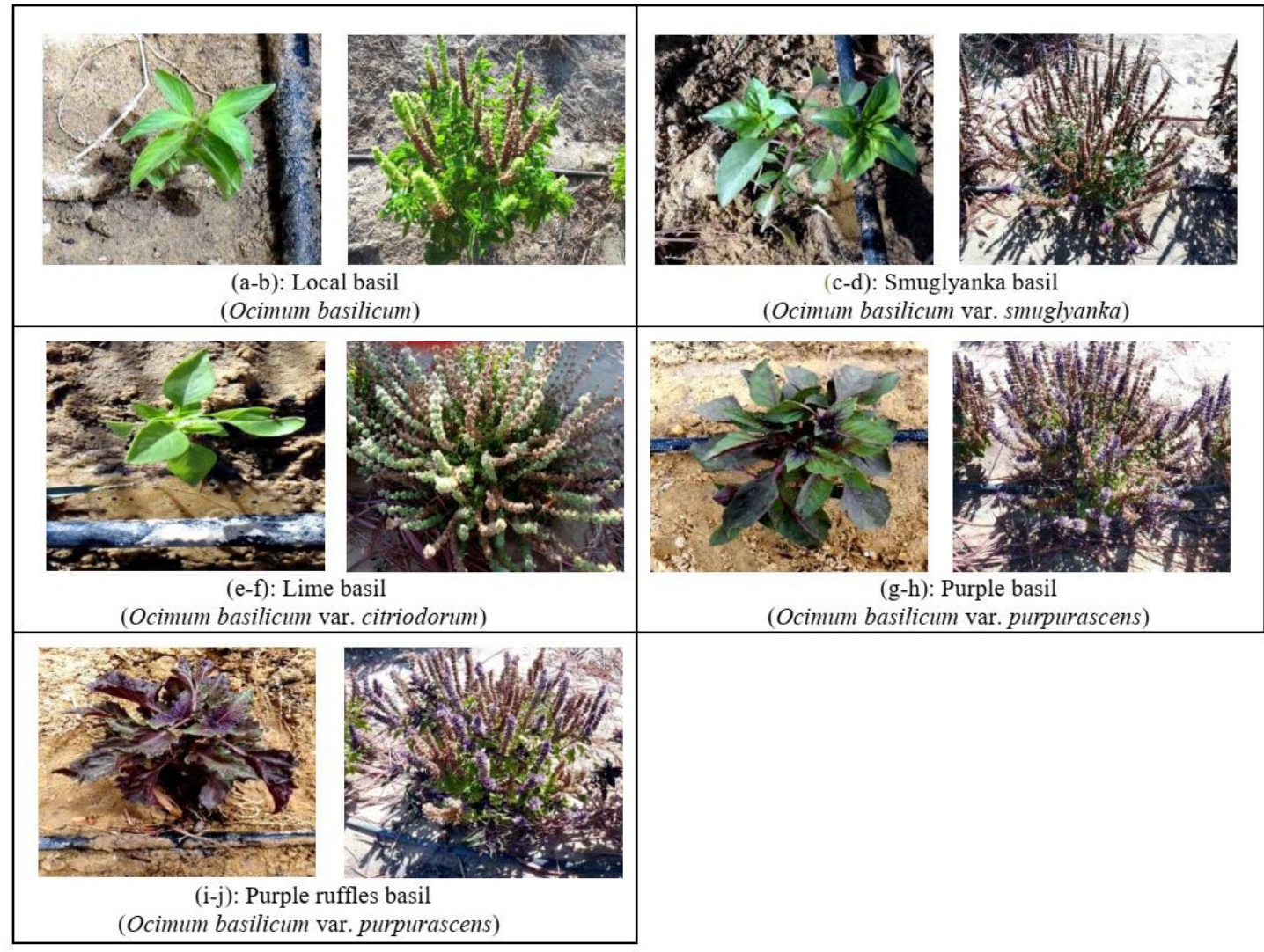

Figure 1: Cultivated varieties at different growth stages. 
GC Ultra Gas Chromatographs (Thermo Scientific Corp., USA) coupled with a Thermo mass spectrometer detector (ISQ Single Quadrupole Mass Spectrometer). The Gas Chromatography (GC)/ Mass Spectrometry (MS) system was equipped with a Trace-5 mass spectrometer (TR-5MS) column ( $30 \mathrm{~m} \times 0.32 \mathrm{~mm}$ i.d., $0.25 \mu \mathrm{m}$ film thickness). Analyses were carried out using helium as a carrier gas at a flow rate of $1.3 \mathrm{ml} /$ minute at a split ratio of 1:10 at the following temperature program: $80^{\circ} \mathrm{C}$ for 1 minute; rising at $4{ }^{\circ} \mathrm{C} /$ minute to $300^{\circ} \mathrm{C}$, and held for 1 minute. The injector and detector were held at $220^{\circ} \mathrm{C}$ and $200^{\circ} \mathrm{C}$, respectively. Diluted samples $(1: 10$ hexane, $\mathrm{v} / \mathrm{v})$ of $1 \mu \mathrm{l}$ of the mixtures were continuously injected. Mass spectra were obtained by electron ionization at $70 \mathrm{eV}$, using a spectral range of $\mathrm{m} / \mathrm{z}$ 45-450. Identification of the compounds depended on comparing the retention times with those of authentic samples, and a library mass spectrum was built up from pure substances, components of known oils, and MS literature data [26-31].

\section{RESULTS AND DISCUSSION}

\subsection{Effect of Organic Fertilization}

Data presented in Tables 3-5 revealed that increasing compost manure to $48 \mathrm{~m}^{3} /$ hectare significantly increased plant height and fresh and dry herb yields (ton/hectare) in all cuts. The change percentages over control treatment were $9.27 \%, 25.95 \%$, and $26.83 \% ; 10.19 \%, 19.22 \%$, and $20.19 \%$; and $8.28 \%, 32.73 \%$, and $29.73 \%$ for the first, second, and third cuts, respectively. Likewise, the obtained results in Tables 6-7 showed that increasing the amount of applied manure to soil significantly boosted the accumulation of essential oil percentage and oil yield among all cuts of the two seasons. The change percentage over control treatment was $20.37 \%$ and $53.41 \% ; 19.15 \%$ and $43.56 \% ; 15.39 \%$ and $40.92 \%$ for the first, second, and third cuts, respectively. On the other side, the lowest compost level $\left(24 \mathrm{~m}^{3} /\right.$ hectare $)$ offered the lowermost parameters. The increment in essential oil yield may be due to the increment of essential oil $\%$ and/or mass production of herb.

The enhancing effect of organic fertilization on basil crops under the oasis environments can be due to its role in stress alleviation in plants. This area has poor sandy dune saline soil, irrigation by well with saline water, and a semiarid climate. Thus, the application of organic matter has several benefits there. It releases nutrients slowly, maintains the soil's structural stability, protects the soil against erosion, and improves physical, chemical, and biological properties to increase the overall soil fertility and, consequently, increase plant growth with more metabolites $[32,33]$. The successful role of organic fertilization on sustainable productivity, improving the quantity and quality of basil yield, agrees with numerous researches [34-45].

\subsection{Effect of Varieties}

According to data presented in Tables 3-5, there were remarkable variations between basil varieties in vegetative growth and yield. The significantly highest fresh herb yield/hectare and dry herb yield/hectare were got by purple ruffles variety during the first, second, and third cuts, respectively, followed by purple variety. On the other hand, the lime and smuglyanka varieties showed

Table 3: Effect of compost manure levels, varieties, and their interaction on plant height $(\mathrm{cm})$ (mean values of two successive seasons).

\begin{tabular}{|c|c|c|c|c|}
\hline Compost levels & Varieties & $\begin{array}{c}\text { 1st cut } \\
\text { (12th July) }\end{array}$ & $\begin{array}{c}\text { 2nd cut } \\
\text { (15th September) }\end{array}$ & $\begin{array}{c}\text { 3rd cut } \\
\text { (17th December) }\end{array}$ \\
\hline \multirow{5}{*}{$24 \mathrm{~m}^{3} /$ hectare } & Local & 24.00 & 29.83 & 29.50 \\
\hline & Smuglyanka & 39.00 & 44.00 & 42.00 \\
\hline & Lime & 20.83 & 27.00 & 24.00 \\
\hline & Purple & 29.00 & 35.33 & 33.67 \\
\hline & Purple ruffles & 36.00 & 42.50 & 39.83 \\
\hline \multirow[t]{3}{*}{ Mean } & & 29.77 & 35.73 & 33.80 \\
\hline & Local & 27.50 & 34.67 & 32.67 \\
\hline & Smuglyanka & 41.67 & 48.17 & 44.00 \\
\hline \multirow[t]{3}{*}{$48 \mathrm{~m}^{3} /$ hectare } & Lime & 23.00 & 30.00 & 25.50 \\
\hline & Purple & 32.33 & 39.00 & 38.83 \\
\hline & Purple ruffles & 38.17 & 45.00 & 42.00 \\
\hline \multirow[t]{2}{*}{ Mean } & & 32.53 & 39.37 & 36.60 \\
\hline & Local & 25.75 & 32.25 & 31.09 \\
\hline \multirow{4}{*}{$\begin{array}{l}\text { Over all } \\
\text { means of } \\
\text { varieties }\end{array}$} & Smuglyanka & 40.34 & 46.09 & 43.00 \\
\hline & Lime & 21.92 & 28.50 & 24.75 \\
\hline & Purple & 30.67 & 37.17 & 36.25 \\
\hline & Purple ruffles & 37.09 & 43.75 & 40.92 \\
\hline \multirow{3}{*}{ LSD at 0.05} & Compost levels & 1.66 & 1.43 & 1.23 \\
\hline & Varieties & 2.63 & 2.26 & 1.94 \\
\hline & Compost levels $\times$ varieties & 3.71 & 3.19 & 2.75 \\
\hline
\end{tabular}


Table 4: Effect of compost manure levels, varieties, and their interaction on fresh herb yield (ton/hectare) (mean values of two successive seasons).

$\begin{array}{llccc}\text { Compost levels } & \text { Varieties } & \begin{array}{c}\text { 1st cut } \\ \text { (12th July) }\end{array} & \begin{array}{c}\text { 2nd cut } \\ \text { (15th September) }\end{array} & \begin{array}{c}\text { 3rd cut } \\ \text { (17th December) }\end{array} \\ & \text { Local } & 1.13 & 3.10 & 2.22 \\ 24 \mathrm{~m}^{3} / \text { hectare } & \text { Smuglyanka } & 0.69 & 2.13 & 0.99 \\ & \text { Lime } & 0.82 & 2.44 & 1.35 \\ & \text { Purple } & 1.61 & 4.31 & 2.93 \\ \text { Mean } & \text { Purple ruffles } & & 5.98 & 3.51 \\ & \text { Local } & 2.30 & 3.59 & 2.20 \\ 48 \mathrm{~m}^{3} / \text { hectare } & \text { Smuglyanka } & 1.31 & 3.65 & 3.15 \\ & \text { Lime } & 1.60 & 2.53 & 1.55 \\ \text { Purple } & 0.89 & 2.78 & 3.74 \\ \text { Mean } & \text { Purple ruffles } & 0.98 & 5.36 & 4.37 \\ & & 2.07 & 7.08 & 2.92 \\ \text { Over all } & \text { Local } & 2.69 & 4.28 & 2.69 \\ \text { means of } & \text { Smuglyanka } & 1.65 & 3.38 & 1.27 \\ \text { varieties } & \text { Lime } & 1.37 & 2.33 & 1.58 \\ & \text { Purple } & 0.79 & 2.61 & 3.34 \\ & \text { Purple ruffles } & 0.90 & 4.84 & 3.94 \\ & \text { Compost levels } & 1.84 & 6.53 & 0.12\end{array}$

Table 5: Effect of compost manure levels, varieties, and their interaction on dry herb yield (ton/hectare) (mean values of two successive seasons).

\begin{tabular}{|c|c|c|c|c|}
\hline Compost levels & Varieties & $\begin{array}{c}\text { 1st cut } \\
\text { (12th July) }\end{array}$ & $\begin{array}{c}\text { 2nd cut } \\
\text { (15th September) }\end{array}$ & $\begin{array}{c}\text { 3rd cut } \\
\text { (17th December) }\end{array}$ \\
\hline \multirow{5}{*}{$24 \mathrm{~m}^{3} /$ hectare } & Local & 0.34 & 0.90 & 0.68 \\
\hline & Smuglyanka & 0.19 & 0.59 & 0.32 \\
\hline & Lime & 0.26 & 0.71 & 0.48 \\
\hline & Purple & 0.53 & 1.29 & 1.01 \\
\hline & Purple ruffles & 0.73 & 1.72 & 1.19 \\
\hline \multirow[t]{3}{*}{ Mean } & & 0.41 & 1.04 & 0.74 \\
\hline & Local & 0.49 & 1.07 & 0.93 \\
\hline & Smuglyanka & 0.25 & 0.73 & 0.49 \\
\hline \multirow[t]{3}{*}{$48 \mathrm{~m}^{3} /$ hectare } & Lime & 0.30 & 0.81 & 0.62 \\
\hline & Purple & 0.72 & 1.58 & 1.29 \\
\hline & Purple ruffles & 0.84 & 2.05 & 1.48 \\
\hline \multirow[t]{2}{*}{ Mean } & & 0.52 & 1.25 & 0.96 \\
\hline & Local & 0.42 & 0.99 & 0.81 \\
\hline \multirow{5}{*}{$\begin{array}{l}\text { Over all } \\
\text { means of } \\
\text { varieties }\end{array}$} & Smuglyanka & 0.22 & 0.66 & 0.41 \\
\hline & Lime & 0.28 & 0.76 & 0.55 \\
\hline & Purple & 0.63 & 1.44 & 1.15 \\
\hline & Purple ruffles & 0.79 & 1.89 & 1.34 \\
\hline & Compost levels & 0.02 & 0.07 & 0.05 \\
\hline \multirow[t]{2}{*}{ LSD at 0.05} & Varieties & 0.05 & 0.10 & 0.07 \\
\hline & Compost levels $\times$ varieties & 0.07 & 0.14 & 0.10 \\
\hline
\end{tabular}



Siwa Oasis conditions 2022;10(02):74-88

Table 6: Effect of compost manure levels, varieties, and their interaction on essential oil percentage (mean values of two successive seasons).

\begin{tabular}{|c|c|c|c|c|}
\hline Compost levels & Varieties & $\begin{array}{c}\text { 1st cut } \\
\text { (12th July) }\end{array}$ & $\begin{array}{c}\text { 2nd cut } \\
\text { (15th September) }\end{array}$ & $\begin{array}{c}\text { 3rd cut } \\
\text { (17th December) }\end{array}$ \\
\hline \multirow{5}{*}{$24 \mathrm{~m}^{3} /$ hectare } & Local & 0.64 & 0.58 & 0.45 \\
\hline & Smuglyanka & 0.30 & 0.24 & 0.19 \\
\hline & Lime & 0.41 & 0.30 & 0.24 \\
\hline & Purple & 0.51 & 0.46 & 0.38 \\
\hline & Purple ruffles & 0.83 & 0.75 & 0.70 \\
\hline \multirow[t]{3}{*}{ Mean } & & 0.54 & 0.47 & 0.39 \\
\hline & Local & 0.79 & 0.70 & 0.49 \\
\hline & Smuglyanka & 0.37 & 0.30 & 0.24 \\
\hline \multirow[t]{3}{*}{$48 \mathrm{~m}^{3} /$ hectare } & Lime & 0.52 & 0.40 & 0.37 \\
\hline & Purple & 0.60 & 0.52 & 0.42 \\
\hline & Purple ruffles & 0.95 & 0.89 & 0.75 \\
\hline \multirow[t]{2}{*}{ Mean } & & 0.65 & 0.56 & 0.45 \\
\hline & Local & 0.72 & 0.64 & 0.47 \\
\hline \multirow{5}{*}{$\begin{array}{l}\text { Over all } \\
\text { means of } \\
\text { varieties }\end{array}$} & Smuglyanka & 0.34 & 0.27 & 0.22 \\
\hline & Lime & 0.47 & 0.35 & 0.31 \\
\hline & Purple & 0.56 & 0.49 & 0.40 \\
\hline & Purple ruffles & 0.89 & 0.82 & 0.73 \\
\hline & Compost levels & 0.02 & 0.01 & 0.02 \\
\hline \multirow[t]{2}{*}{ LSD at 0.05} & Varieties & 0.03 & 0.02 & 0.03 \\
\hline & Compost levels $\times$ varieties & 0.04 & 0.03 & 0.04 \\
\hline
\end{tabular}

Table 7: Effect of compost manure levels, varieties, and their interaction on essential oil yield/hectare (1) (mean values of two successive seasons).

\begin{tabular}{|c|c|c|c|c|}
\hline Compost levels & Varieties & $\begin{array}{c}\text { 1st cut } \\
\text { (12th July) }\end{array}$ & $\begin{array}{c}\text { 2nd cut } \\
\text { (15th September) }\end{array}$ & $\begin{array}{c}\text { 3rd cut } \\
\text { (17th December) }\end{array}$ \\
\hline \multirow{5}{*}{$24 \mathrm{~m}^{3} /$ hectare } & Local & 2.22 & 5.33 & 3.11 \\
\hline & Smuglyanka & 0.45 & 1.33 & 0.45 \\
\hline & Lime & 0.89 & 2.22 & 1.33 \\
\hline & Purple & 2.67 & 5.78 & 4.00 \\
\hline & Purple ruffles & 6.22 & 12.89 & 8.45 \\
\hline \multirow[t]{3}{*}{ Mean } & & 2.49 & 5.51 & 3.47 \\
\hline & Local & 4.00 & 7.56 & 4.45 \\
\hline & Smuglyanka & 0.89 & 2.22 & 1.33 \\
\hline \multirow[t]{3}{*}{$48 \mathrm{~m}^{3} /$ hectare } & Lime & 1.78 & 3.11 & 2.22 \\
\hline & Purple & 4.45 & 8.45 & 5.33 \\
\hline & Purple ruffles & 8.00 & 18.22 & 11.11 \\
\hline \multirow[t]{2}{*}{ Mean } & & 3.82 & 7.91 & 4.89 \\
\hline & Local & 3.11 & 6.45 & 3.78 \\
\hline Over all & Smuglyanka & 0.67 & 1.78 & 0.89 \\
\hline means of & Lime & 1.34 & 2.67 & 1.78 \\
\hline \multirow[t]{3}{*}{ varieties } & Purple & 3.56 & 7.12 & 4.67 \\
\hline & Purple ruffles & 7.11 & 15.56 & 9.78 \\
\hline & Compost levels & 0.24 & 0.38 & 0.19 \\
\hline \multirow[t]{2}{*}{ LSD at 0.05} & Varieties & 0.38 & 0.60 & 0.31 \\
\hline & Compost levels $\times$ varieties & 0.53 & 0.84 & 0.43 \\
\hline
\end{tabular}


lower measurements than the local ones. The increments of purple ruffles over local variety were $82.48 \%$ and $88.10 \% ; 93.20 \%$ and $90.91 \% ; 46.47 \%$ and $65.43 \%$ for the first, second, and third cuts, respectively. The increments in the purple variety over local basil were $34.31 \%$ and $50 \% ; 43.20 \%$ and $45.46 \% ; 24.16 \%$ and $41.98 \%$ for the first, second, and third cuts, correspondingly. Regarding the effect on essential oil yield, the results presented in Tables 6-7 revealed that only purple ruffles and purple variety produced the significantly maximum oil yield over the local basil. The purple ruffles oil increased by $128.62 \%, 90.91 \%$, and $158.73 \%$ respecting the first, second, and third cuts. Besides, the purple basil oil increments were $14.47 \%, 10.39 \%$, and $23.55 \%$ concerning the first, second, and third cuts, respectively. Meantime, the other foreign varieties of lime and smuglyanka showed lower measurements than the local basil.

The superior productivity of purple ruffles and purple varieties can result from their more tolerance of abiotic stresses than other varieties under existing environments. This area has high temperatures during the summer months and moderate temperatures in autumn and spring, in addition to saline soil and saline irrigation resource. Purple basils contain high concentrations of total anthocyanins, flavonoid compounds that increase plant resistance to abiotic stresses. Anthocyanins play a role in foliar photoprotection during stress impairing photosynthesis such as heat, salinity, and excess solar radiation stresses and consequently contribute to high basil yield [46-52]. Also, these results are in harmony with the literature that points out that variation between basil cultivars for herb growth and oil yield characteristics may be attributed to genetic diversity due to hybridization, targeted cultivation, and breeding practices for desired results morphochemotypes [53-57].

\subsection{Effect of the Interaction Between Organic Fertilization and Varieties}

Concerning the interaction between organic fertilization and varieties, the significantly pronounced increments in fresh and dry herb yields resulted by cultivation purple ruffles variety under application of compost at $48 \mathrm{~m}^{3} /$ hectare, followed by application $48 \mathrm{~m}^{3}$ compost/hectare and planting purple variety than other treatments in both cuts (Tables 3-5). Correspondingly, the increasing percentages of the first treatment mentioned above were $138.05 \%$ and $147.06 \% ; 128.39 \%$ and $127.78 \% ; 96.85 \%$ and $117.65 \%$ for the first, second, and third cuts, respectively. Also, the second previous treatment's increment percentage was $83.19 \%$ and $111.77 \% ; 72.90 \%$ and $75.56 \% ; 68.47 \%$ and $89.71 \%$ concerning the first, second, and third cuts, respectively. Furthermore, the recorded essential oil data ( $\%$ and $1 /$ hectare) aligned with the vegetative growth. The significantly highest quantities of oil yield were obtained by adding $48 \mathrm{~m}^{3}$ compost/ hectare to purple ruffles variety plants, followed by adding $48 \mathrm{~m}^{3}$ compost/hectare for purple variety (Tables 6-7). Similarly, these increments of $48 \mathrm{~m}^{3}$ compost/hectare and planting purple ruffles variety were $260.36 \%, 241.84 \%$, and $257.24 \%$ for the first, second, and third cuts, respectively. The increment percentages of $48 \mathrm{~m}^{3}$ compost/hectare and planting purple variety over local basil were $100.45 \%, 58.54 \%$, and $71.38 \%$ about the first, second, and third cuts, successively.
Here, there is a significant rise in yield because treatments of fertilizing with $48 \mathrm{~m}^{3}$ compost/hectare and cultivating anthocyaninrich varieties can be due to their combined stimulatory effect on plant growth under stresses, as discussed before. Also, it is noteworthy that essential oil yield varied according to harvest time as the maximum quantity of oil was distilled from the summer cut followed by autumn and then spring ones. These findings align with numerous investigators' opinions that basil biomass and oil yield parameters vary depending on environmental conditions, agriculture practices, and genetic variability [58-63].

Moreover, data presented in Table 8 showed the influence of the interaction between treatments on essential oil constituents (second cut, summer cut), and the identified compounds are clarified below.

Concerning the treatment of fertilization with compost at $24 \mathrm{~m}^{3} /$ hectare and planting local basil variety, the main components of the oil were 1,8-cineole (56.86\%), 1-linalool (11.13\%), and cinnamic acid methyl ester $(8.45 \%)$. Regarding the treatment of applying compost at $48 \mathrm{~m}^{3} /$ hectare and planting local variety, the major components of the oil were 1,8-cineole $(46.47 \%)$, cinnamic acid methyl ester (22.53\%), and 1-linalool (10.04\%). As for the treatment using compost at $24 \mathrm{~m}^{3} /$ hectare and planting lime variety, the high compounds of oil were cinnamic acid methyl ester (17.83\%), bornyl acetate $(12.17 \%)$, l-linalool $(11.99 \%)$, citral $(9.47 \%)$, and nerol $(9.15 \%)$, whereas for the treatment using compost at $48 \mathrm{~m}^{3} /$ hectare and planting lime variety, the high oil compounds were citral (22.85\%), 1-linalool (20.60\%), nerol (17.77\%), (-)-caryophyllene oxide $(10.00 \%)$, and estragole $(0.66 \%)$. Regarding the treatment of adding compost at $24 \mathrm{~m}^{3} /$ hectare and cultivating smuglyanka variety, the maximum compounds of oil were camphor $(40.19 \%)$, 1,8-cineole (18.83\%), and 1-linalool (17.04\%); on the other side, regarding the treatment of adding compost at $48 \mathrm{~m}^{3} /$ hectare and cultivating smuglyanka variety, the maximum compounds of oil were 1-linalool $(35.09 \%)$, camphor $(28.69 \%)$, and 1,8-cineole $(19.73 \%)$. In connection with the treatment of adding compost at 24 $\mathrm{m}^{3} /$ hectare and cultivating purple variety, the rich aroma constituents were 1-linalool $(54.11 \%)$ and 1,8 -cineole $(31.53 \%)$, while in the treatment of adding compost at $48 \mathrm{~m}^{3} /$ hectare and cultivating purple variety, the rich aroma constituents were 1-linalool (50.95\%) and 1,8-cineole (29.67\%). As for the treatment of using compost at $24 \mathrm{~m}^{3} /$ hectare and farming purple ruffles variety, the chief aroma components were 1-linalool (35.83\%), 1,8-cineole (14.21\%), and estragole $(1.79 \%)$. Meanwhile, for treatment of using compost at $48 \mathrm{~m}^{3} /$ hectare and farming purple ruffles variety, the chief aroma components were 1-linalool (36.77\%), 1,8-cineole (14.50\%), and estragole $(1.83 \%)$.

Also, data presented in Table 9 show the influence of the interaction between treatments on essential oil chemical composition (third cut, autumn cut), and the identified compounds are clarified below.

About the treatment of compost at $24 \mathrm{~m}^{3} /$ hectare and growing local basil variety, the most components of the oil were cinnamic acid methyl ester (30.07\%), 1,8-cineole (21.12\%), 1-linalool (17.21\%), bornyl acetate (13.25\%), and tau-cadinol (10.09\%). On the other hand, increasing compost to $48 \mathrm{~m}^{3} /$ hectare and growing the local variety, the most components of the oil were cinnamic acid methyl ester (44.55\%), 1,8-cineole (23.58\%), 1-linalool (12.64\%), and 
Siwa Oasis conditions 2022;10(02):74-88

Table 8: Effect of the interaction between treatments on essential oil composition (\%) (2nd cut-summer cut).

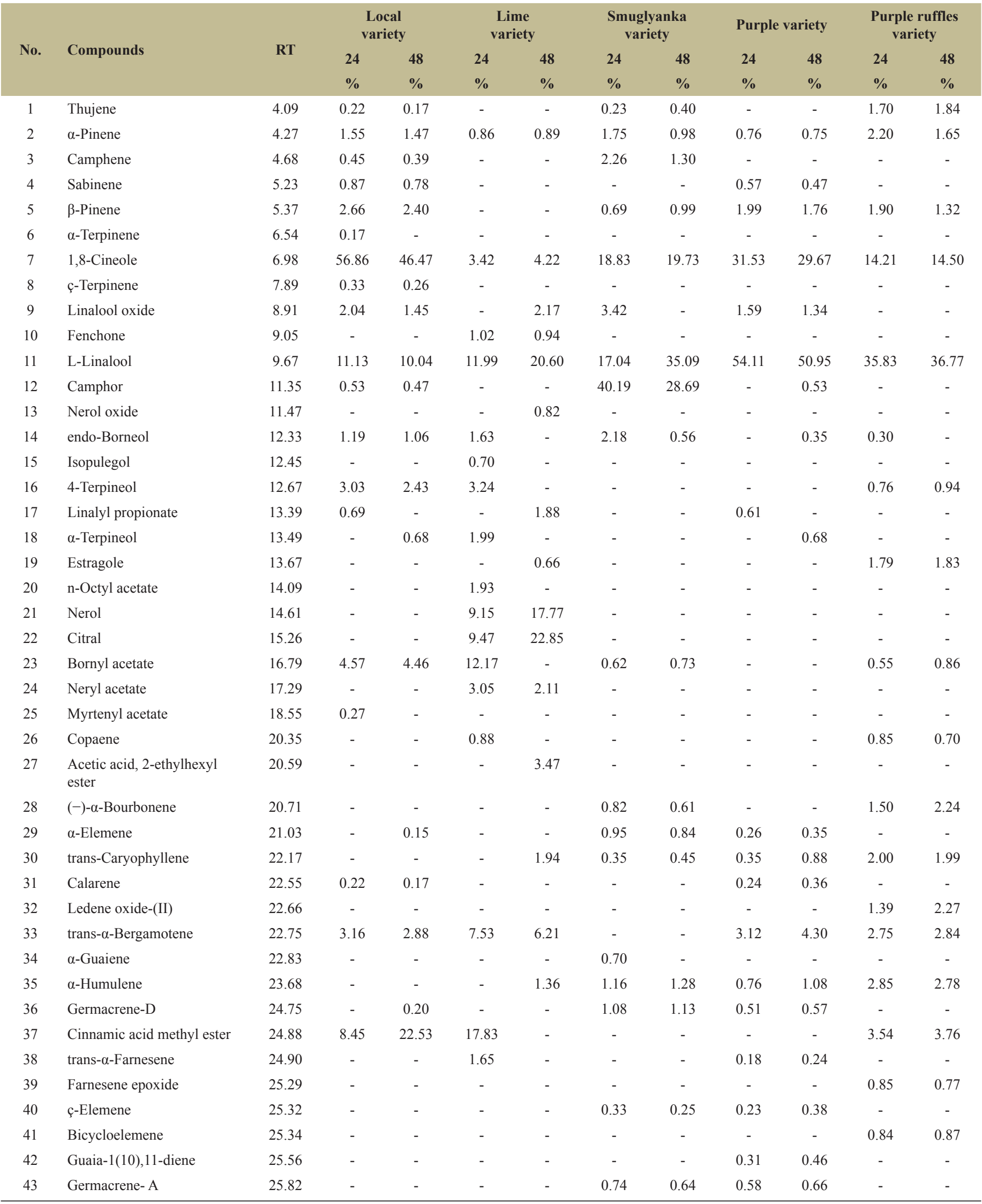




\begin{tabular}{|c|c|c|c|c|c|c|c|c|c|c|c|c|}
\hline \multirow{3}{*}{ No. } & \multirow{3}{*}{ Compounds } & \multirow{3}{*}{ RT } & \multicolumn{2}{|c|}{$\begin{array}{l}\text { Local } \\
\text { variety }\end{array}$} & \multicolumn{2}{|c|}{$\begin{array}{l}\text { Lime } \\
\text { variety }\end{array}$} & \multicolumn{2}{|c|}{$\begin{array}{c}\text { Smuglyanka } \\
\text { variety }\end{array}$} & \multicolumn{2}{|c|}{ Purple variety } & \multicolumn{2}{|c|}{$\begin{array}{c}\text { Purple ruffles } \\
\text { variety }\end{array}$} \\
\hline & & & 24 & 48 & 24 & 48 & 24 & 48 & 24 & 48 & 24 & 48 \\
\hline & & & $\%$ & $\%$ & $\%$ & $\%$ & $\%$ & $\%$ & $\%$ & $\%$ & $\%$ & $\%$ \\
\hline 44 & ç-Cadinene & 26.10 & 0.79 & 0.71 & - & - & - & - & 0.35 & - & 0.90 & 0.95 \\
\hline 45 & ç-Muurolene & 26.14 & - & - & 1.35 & - & 1.41 & 1.55 & - & 0.49 & - & - \\
\hline 46 & Junipene & 26.50 & - & - & - & - & - & - & - & - & 0.74 & 0.82 \\
\hline 47 & $\alpha$-Bisabolol & 26.87 & - & - & - & - & - & - & - & - & 2.75 & 1.81 \\
\hline 48 & Farnesol & 27.32 & - & - & - & - & - & - & - & - & 2.89 & 2.91 \\
\hline 49 & $\alpha$-Bisabolene & 27.34 & - & - & - & 0.74 & - & - & - & - & - & - \\
\hline 50 & Veridiflorol & 28.33 & - & - & - & 0.83 & - & - & 0.93 & 1.77 & 1.35 & - \\
\hline 51 & $\begin{array}{l}\text { Trans-Z- } \alpha \text {-Bisabolene } \\
\text { epoxide }\end{array}$ & 28.44 & - & - & - & - & - & - & - & - & 2.73 & 2.57 \\
\hline 52 & 13-Octadecenal & 29.50 & - & - & - & - & - & - & - & - & 1.89 & 1.79 \\
\hline 53 & (-)-Caryophyllene oxide & 29.96 & 0.45 & 0.30 & 7.80 & 10.00 & 1.78 & 1.83 & 0.19 & 0.34 & 2.62 & 2.87 \\
\hline 54 & Humulene oxide & 30.00 & - & - & 1.26 & - & 1.12 & 1.27 & 0.15 & 0.30 & - & - \\
\hline 55 & Zierone & 30.21 & - & - & - & - & - & - & - & - & 1.79 & 1.96 \\
\hline 56 & p-Mentha-2,5-dien-7-ol, cis & 30.48 & - & - & - & - & - & - & - & - & 1.65 & 1.85 \\
\hline 57 & Bergamotol, Z- $\alpha$ - trans & 30.92 & - & - & - & - & - & - & - & - & 1.85 & 1.92 \\
\hline 58 & $(+)$-3-Carene & 31.21 & - & - & - & - & - & - & - & - & 0.95 & 0.70 \\
\hline \multirow[t]{4}{*}{59} & .tau.-Cadinol & 31.32 & 0.37 & 0.53 & 1.08 & 0.54 & 2.35 & 1.68 & 0.68 & 1.32 & 2.08 & 1.92 \\
\hline & Total identified compounds & & 100 & 100 & 100 & 100 & 100 & 100 & 100 & 100 & 100 & 100 \\
\hline & Total hydrocarbon compounds & & 10.42 & 9.58 & 12.27 & 11.14 & 12.47 & 10.42 & 10.21 & 12.75 & 19.18 & 18.7 \\
\hline & Total oxygenated compounds & & 89.58 & 90.42 & 87.73 & 88.86 & 87.53 & 89.58 & 89.79 & 87.25 & 80.82 & 81.3 \\
\hline
\end{tabular}

$\mathrm{RT}=$ Retention time.

Table 9: Effect of the interaction between treatments on essential oil composition (\%) (3rd cut-autumn cut).

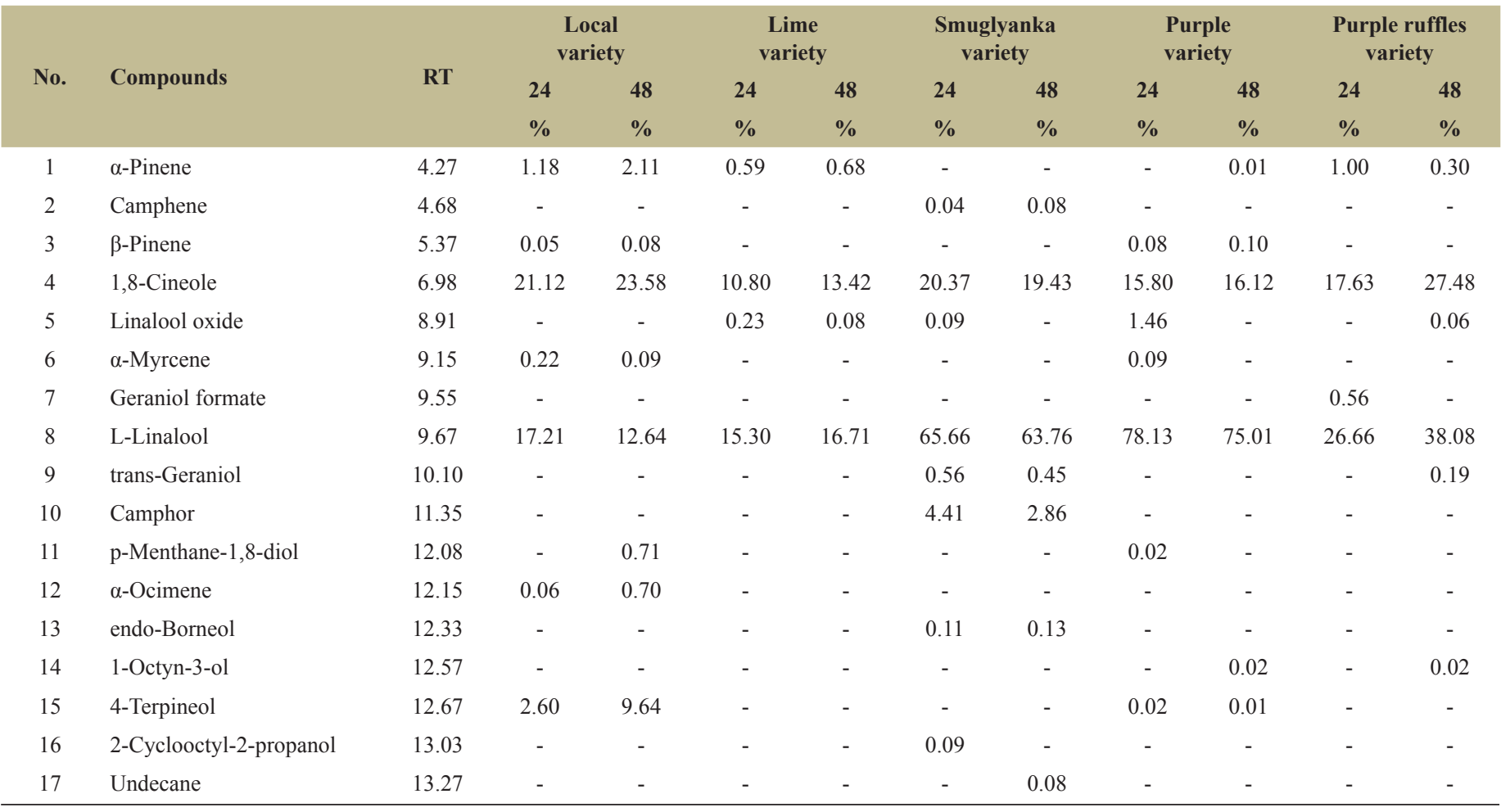



Siwa Oasis conditions 2022;10(02):74-88

\begin{tabular}{|c|c|c|c|c|c|c|c|c|c|c|c|c|}
\hline \multirow{2}{*}{ No. } & \multirow{2}{*}{ Compounds } & \multirow{2}{*}{ RT } & \multicolumn{2}{|c|}{$\begin{array}{l}\text { Local } \\
\text { variety }\end{array}$} & \multicolumn{2}{|c|}{$\begin{array}{l}\text { Lime } \\
\text { variety }\end{array}$} & \multicolumn{2}{|c|}{$\begin{array}{c}\text { Smuglyanka } \\
\text { variety }\end{array}$} & \multicolumn{2}{|c|}{$\begin{array}{l}\text { Purple } \\
\text { variety }\end{array}$} & \multicolumn{2}{|c|}{$\begin{array}{c}\text { Purple ruffles } \\
\text { variety }\end{array}$} \\
\hline & & & $\%$ & $\%$ & $\%$ & $\%$ & $\%$ & $\%$ & $\%$ & $\%$ & $\%$ & $\%$ \\
\hline 18 & $\alpha$-Citronellol & 13.56 & - & - & - & - & - & - & - & - & - & 0.01 \\
\hline 19 & Estragole & 13.67 & - & - & 0.84 & 0.93 & - & - & 0.02 & 0.02 & 8.61 & 29.32 \\
\hline 20 & n-Octyl acetate & 14.09 & - & - & 0.20 & 1.00 & - & - & - & - & - & - \\
\hline 22 & 2-Methyl-3-buten-2-ol & 14.32 & - & 0.06 & - & - & - & - & - & - & - & - \\
\hline 23 & 1,6-Heptadien-4-ol & 14.41 & - & 0.05 & - & - & - & - & - & - & - & - \\
\hline 24 & Nerol & 14.61 & - & - & 12.79 & 13.20 & - & - & - & - & - & - \\
\hline 25 & Terpendiol II & 14.77 & 2.11 & - & - & - & - & - & - & - & - & - \\
\hline 26 & 4-Undecyne & 14.81 & - & - & 012 & 0.08 & - & - & - & - & - & - \\
\hline 30 & p-Menth-1-en-8-ol & 16.09 & - & - & 0.91 & 0.40 & 0.09 & 0.26 & 0.12 & 0.01 & - & - \\
\hline 31 & 1-Octyl acetate & 16.66 & - & - & - & - & - & - & 0.10 & - & - & - \\
\hline 32 & n-Nonyl acetate & 16.72 & - & - & - & - & - & - & - & 0.09 & - & - \\
\hline 33 & Bornyl acetate & 16.79 & 13.25 & - & - & - & - & - & - & - & - & - \\
\hline 34 & Dihydrocarvyl acetate & 16.93 & - & - & - & - & - & - & 0.01 & 0.01 & 0.03 & - \\
\hline 35 & Neryl acetate & 17.29 & - & - & 1.30 & 2.20 & - & - & - & - & - & - \\
\hline 36 & Linalyl acetate & 19.00 & - & - & 0.65 & 0.41 & - & - & 0.01 & - & - & 0.02 \\
\hline 37 & Copaene & 20.35 & 0.18 & - & - & - & - & - & - & - & 0.52 & - \\
\hline 38 & $\alpha$-Bourbonene & 20.71 & - & - & - & - & - & - & 0.06 & 0.15 & - & - \\
\hline 45 & Aromadendrene & 22.58 & - & - & - & - & 0.15 & - & - & - & - & - \\
\hline 46 & Valencene & 22.60 & - & - & - & - & 0.02 & - & - & - & - & - \\
\hline 47 & trans- $\alpha$-Bergamotene & 22.75 & - & - & 3.00 & 3.11 & 0.06 & - & - & - & 11.76 & 2.11 \\
\hline 48 & $\alpha$-Guaiene & 22.83 & - & - & - & - & - & 0.24 & - & - & 1.47 & - \\
\hline 49 & $\alpha$-Selinene & 22.90 & - & - & - & - & 0.02 & - & - & - & - & - \\
\hline 50 & Humuladienone & 22.95 & - & - & - & - & 0.26 & - & - & 0.39 & - & - \\
\hline 51 & ç-Dodecalactone & 23.10 & - & - & 0.24 & 0.18 & - & - & - & - & - & - \\
\hline 52 & $\alpha$-Humulene & 23.68 & - & 0.09 & - & 1.03 & 0.04 & 0.16 & 1.77 & 1.96 & 1.06 & 0.20 \\
\hline 53 & cis- $\alpha$-Bisabolene & 23.71 & - & - & 0.39 & 0.45 & 0.06 & 0.19 & - & - & - & - \\
\hline 54 & $\alpha$-Bulnesene & 24.24 & - & - & - & - & 0.04 & - & - & - & - & - \\
\hline 55 & Germacrene-D & 24.75 & - & 0.30 & 0.51 & 0.73 & 0.12 & 0.42 & 0.14 & 0.14 & 3.27 & 0.14 \\
\hline 56 & $\alpha$-Amorphene & 24.87 & - & 0.58 & - & - & - & & - & - & - & - \\
\hline 57 & Cinnamic acid methyl ester & 24.88 & 30.07 & 44.55 & 2.08 & 2.26 & 0.21 & 0.30 & 0.04 & 0.38 & - & - \\
\hline 58 & trans- $\alpha$-Farnesene & 24.90 & 0.08 & - & - & - & 0.03 & - & 0.02 & 0.04 & - & - \\
\hline 59 & Iso-isopulegyl acetate & 25.06 & - & - & - & - & - & 0.06 & - & - & - & - \\
\hline 60 & Farnesene epoxide & 25.29 & - & - & 0.29 & 0.35 & - & - & - & - & 0.08 & 0.02 \\
\hline 61 & Nerolidol & 25.60 & - & - & 0.91 & 1.84 & 0.04 & - & 0.01 & - & - & - \\
\hline 62 & Germacrene- A & 25.82 & - & - & - & - & - & - & - & - & - & 0.09 \\
\hline
\end{tabular}




\begin{tabular}{|c|c|c|c|c|c|c|c|c|c|c|c|c|}
\hline \multirow{2}{*}{ No. } & \multirow{2}{*}{ Compounds } & \multirow{2}{*}{ RT } & \multicolumn{2}{|c|}{$\begin{array}{c}\text { Local } \\
\text { variety }\end{array}$} & \multicolumn{2}{|c|}{$\begin{array}{l}\text { Lime } \\
\text { variety }\end{array}$} & \multicolumn{2}{|c|}{$\begin{array}{l}\text { Smuglyanka } \\
\text { variety }\end{array}$} & \multicolumn{2}{|c|}{$\begin{array}{l}\text { Purple } \\
\text { variety }\end{array}$} & \multicolumn{2}{|c|}{$\begin{array}{c}\text { Purple ruffles } \\
\text { variety }\end{array}$} \\
\hline & & & $\%$ & $\%$ & $\%$ & $\%$ & $\%$ & $\%$ & $\%$ & $\%$ & $\%$ & $\%$ \\
\hline 63 & Globulol & 25.86 & - & - & - & - & - & - & - & - & - & 0.50 \\
\hline 64 & Myrtenol & 26.00 & - & - & - & - & - & - & 0.06 & - & - & - \\
\hline 65 & ç-Cadinene & 26.10 & - & - & 0.36 & 0.18 & - & - & - & - & 0.05 & - \\
\hline 67 & Longipinene epoxide & 26.25 & - & - & - & - & - & - & 0.08 & 0.01 & - & 0.12 \\
\hline 68 & Dihydromyrcene & 26.29 & - & 0.05 & 0.11 & 0.14 & - & - & - & - & - & - \\
\hline 69 & Spathulenol & 26.33 & 0.74 & - & - & - & - & 0.26 & - & 0.39 & 3.70 & - \\
\hline 70 & 2,6-nonadienol & 26.60 & - & - & - & - & 2.79 & - & - & - & 0.07 & - \\
\hline 71 & 8-Hydroxylinalool & 26.67 & - & - & - & - & - & - & 0.08 & - & - & - \\
\hline 75 & $\alpha$-Bisabolol & 26.87 & - & - & 0.22 & 0.19 & 0.02 & - & 0.20 & - & - & - \\
\hline 76 & R-Limonene & 26.94 & 0.03 & - & - & - & - & - & - & - & - & - \\
\hline 77 & Farnesol & 27.32 & 0.11 & - & 3.22 & 3.51 & - & 0.65 & 0.04 & 0.05 & 0.06 & 0.07 \\
\hline 78 & $\alpha$-Himachalene & 27.41 & - & - & - & - & - & 7.37 & - & - & - & - \\
\hline 79 & ë-Cadinene & 27.45 & - & - & - & - & - & - & 1.32 & - & - & - \\
\hline 80 & Limonene dioxide & 27.57 & - & - & - & - & - & - & - & 1.60 & - & - \\
\hline 81 & $\alpha$-Eudesmol & 27.60 & - & - & - & - & - & 0.14 & - & - & - & - \\
\hline 82 & $\alpha$-Cedrenoxide & 28.09 & - & - & - & - & - & 0.11 & - & - & - & - \\
\hline 83 & Veridiflorol & 28.33 & - & - & - & - & 0.09 & - & - & 0.58 & 6.40 & - \\
\hline 89 & $(+)$-Oxo- $\alpha$-ylangene & 29.60 & - & - & - & - & - & 0.05 & - & - & - & - \\
\hline 90 & (-)-Caryophyllene oxide & 29.96 & 0.90 & 0.13 & - & - & 2.35 & 0.52 & - & 0.15 & 1.49 & - \\
\hline 91 & Bergamotol, Z- $\alpha$-trans & 30.92 & - & - & - & - & 0.03 & - & 0.06 & 0.32 & - & - \\
\hline 92 & .tau.-Cadinol & 31.32 & 10.09 & 4.30 & - & - & 1.56 & - & - & - & - & - \\
\hline 93 & $\begin{array}{l}\text { 2,5-Dimethylhex-3-yne- } \\
\text { 2,5-diol }\end{array}$ & 31.47 & - & - & - & - & - & 0.07 & - & - & - & - \\
\hline & Total identified compounds & & 100 & 100 & 100 & 100 & 100 & 100 & 100 & 100 & 100 & 100 \\
\hline & Total hydrocarbon compounds & & 1.80 & 4.00 & 18.28 & 9.85 & 0.77 & 9.20 & 3.54 & 4.19 & 34.58 & 4.00 \\
\hline & Total oxygenated compounds & & 98.20 & 96.00 & 81.72 & 90.15 & 99.23 & 90.80 & 96.46 & 95.81 & 65.42 & 96.00 \\
\hline
\end{tabular}

$\mathrm{RT}=$ Retention time

4-terpineol (9.64\%). Regarding supplying compost at $24 \mathrm{~m}^{3} /$ hectare and planting lime variety, the majority compounds of oil were citral $(30.50 \%)$, l-linalool $(15.30 \%)$, nerol $(12.79 \%)$, and 1,8-cineole (10.80\%). Besides supplying compost at $48 \mathrm{~m}^{3 /}$ hectare and planting lime variety, the majority compounds of oil were citral (32.62\%), 1-linalool (16.71\%), and nerol (13.20\%). For the treatment of adding compost at $24 \mathrm{~m}^{3} /$ hectare and cultivating smuglyanka variety, the principal fragrant oil components were 1-linalool (65.66\%) and 1,8-cineole (20.37\%), while the treatment of adding compost at $48 \mathrm{~m}^{3} /$ hectare and cultivating smuglyanka variety, the principal oil components were l-linalool $(63.76 \%)$ and 1,8-cineole (19.43\%). Concerning fertilization with compost at $24 \mathrm{~m}^{3} /$ hectare and planting purple variety, the maximum oil fractions were 1-linalool $(78.13 \%)$ and 1,8-cineole (15.80\%). For fertilization with compost at $48 \mathrm{~m}^{3} /$ hectare and planting purple variety, the maximum oil fractions were l-linalool (75.01\%) and 


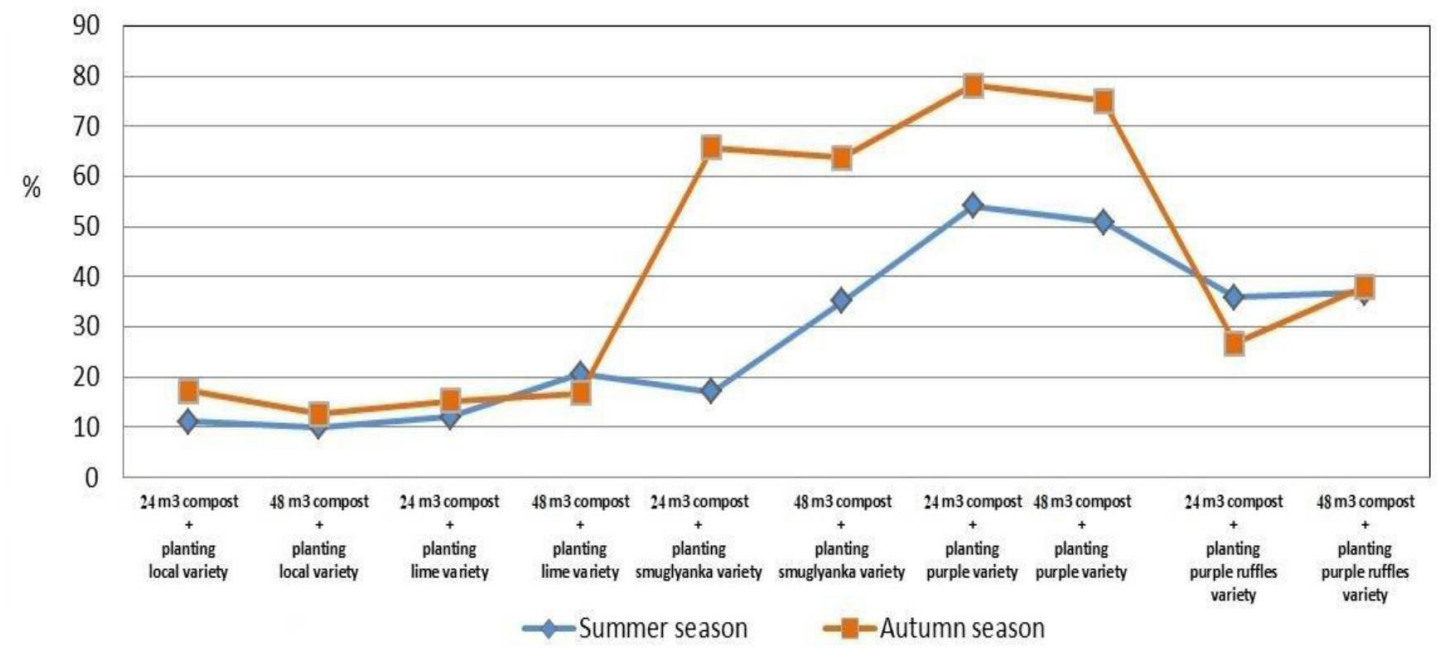

Figure 2: Effect of interaction between treatments on linalool content of essential oil.

1,8-cineole (16.12\%). Concerning using compost at $24 \mathrm{~m}^{3} /$ hectare and cultivating purple ruffles variety, the high oil constituents were l-linalool $(26.66 \%)$, 1,8-cineole $(17.63 \%)$, calarene $(8.67 \%)$, and estragole $(8.61 \%)$. On the contrary, using compost at 48 $\mathrm{m}^{3} /$ hectare and cultivating purple ruffles variety, the high oil constituents were l-linalool (38.08\%), estragole $(29.32 \%)$, and 1,8-cineole (27.48\%).

These results revealed that although the local basil oil is considered a linalool chemotype, its chemical composition was affected by the high salinity found under this location and its meteorological data. The dominated oil components were 1,8-cineole and cinnamic acid methyl ester while containing poor linalool (Fig. 2). Thus, high linalool chemotype varieties were required.

Secondary metabolites of medicinal and aromatic plants have great importance. Linalool-rich essential oils exhibit various biological activities such as antimicrobial, anti-inflammatory, anticancer, and antioxidant properties. Several in vivo studies have confirmed different effects of linalool on the central nervous system. Application of linalool enhances a specific scent to domestic products such as soaps, detergents, and shampoos. Linalool is also an essential compound for the industrial production of various fragrance chemicals and a lead compound in synthesizing vitamins A and E [64-67].

The GC/MS analysis revealed that smuglyanka, purple, and purple ruffles oils were linalool chemotypes except for lime oil which was citral chemotype (Fig. 2). Also, the results indicated that increasing soil organic matter boosted some oil components' accumulation while decreasing others. Besides, oils of the autumn season contained higher linalool and lower 1,8-cineole than summer ones. Likewise, the autumn season's extracted oils had higher cinnamic acid methyl ester and citral contents than summer ones for local and lime basil, respectively.

Estragole is another component that determines oil quality and safety. The leaves of basil and basil oil are possibly unsafe when taken by mouth as a medicine in the long term. These contain estragole, a chemical that may increase the risk of getting liver cancer. It is suspected to be carcinogenic and genotoxic $[68,69]$.
Thus, low or poor estragole basil oils are preferred commercially [70]. The given data in Tables 8 and 9 showed that all treatments contained no traces of estragole (less than 1\%) except for the treatments of compost at 24 or $48 \mathrm{~m}^{3} /$ hectare and cultivating purple ruffles variety $(1.79 \%-29.32 \%)$. These percentages increased as organic fertilization increased in the autumn cut than in summer one.

The results are in harmony with previous studies [71-73], which mentioned that aroma components of basil oil differ according to cultivation practices, chemotype, and season effect. Additionally, the detected essential oil compounds by GC/MS analysis are in harmony with previous studies [74,75].

From the preceding data and Figure 2, yield attributes of varieties at $48 \mathrm{~m}^{3}$ compost/hectare could be summarized as follows:

- Local basil: total fresh herb yield 8.40 tons/hectare, total dry herb yield 2.49 ton/hectare, oil percent $0.49 \%-0.79 \%$ (third and first cuts, resp.), total oil yield 16.01 1/hectare, oil linalool content $10.04 \%-12.64 \%$ (second and third cuts, resp.), oil estragole content $0.00 \%$, and typical basil flavor.

- Purple ruffles basil: total fresh herb yield 14.14 tons/ hectare, total dry herb yield 4.37 tons/hectare, oil percent $0.75 \%-0.95 \%$ (third and first cuts, resp.), total oil yield 37.33 1/hectare, oil linalool content $36.77 \%-38.08 \%$ (second and third cuts, resp.), oil estragole content $1.83 \%-29.32 \%$ (second and third cuts, resp.), and flavor reminiscent of cinnamon and licorice.

- Purple basil: total fresh herb yield 11.17 tons/hectare, total dry herb yield 3.59 tons/hectare, oil percent $0.42 \%-0.60 \%$ (third and first cuts, resp.), total oil yield $18.23 \mathrm{l} /$ hectare, oil linalool content $50.95 \%-75.01 \%$ (second and third cuts, resp.), oil estragole content $0.00 \%-0.02 \%$ (second and third cuts, resp.), and clove flavor.

- Smuglyanka basil: total fresh herb yield 4.97 tons/hectare, total dry herb yield 1.47 tons/hectare, oil percent $0.24 \%-0.37 \%$ (third and first cuts, resp.), total oil yield 4.44 1/hectare, oil linalool content $35.09 \%-63.76 \%$ (second and third cuts, resp.), oil estragole content $0.00 \%$, and clove flavor.

- Lime basil: total fresh herb yield 5.56 tons/hectare, total dry 
herb yield 1.73 tons/hectare, oil percent $0.37 \%-0.52 \%$ (third and first cuts, resp.), total oil yield $7.11 \mathrm{l} /$ hectare, oil linalool content $20.60 \%-16.71 \%$ (second and third cuts, resp.), oil estragole content $0.66 \%-0.93 \%$ (second and third cuts, resp.), oil citral content $22.85 \%-32.62 \%$ (second and third cuts, resp.), and citrus flavor.

Accordingly, the purple basil had the best quantity and quality parameters. It yielded higher fresh and dry herb yields/hectare, oil yield/hectare, maximum linalool, minimum estragole, and another attractive flavor than the local basil. Also, purple basil had a suitable color during autumn and spring. Therefore, purple basil cultivation is recommended for different investment purposes. Its leaves have a beautiful, coppery glow, and slightly spicy taste with a strong clove flavor. It is used in salads, for pesto, and adding beautiful color to dishes. It contains many vitamins, minerals, and fiber. It is used medicinally for its antioxidants and antibacterial properties; oil boosts the immune system and combats aging and skin ailments. It is suitable for fresh or dry production and preparing delicious flavored tea blends [76,77]. Also, oil of this variety is a rich source for the isolation of linalool compound.

Finally, research should be achieved on lime basil variety to improve its productivity to supply the local markets with this valuable citrus flavor resource.

\section{CONCLUSION}

Based on the split-plot design of this experiment, we studied the effect of organic fertilization, varieties, and their interactions on basil at Siwa Oasis. We endorsed producing maximum yield characters (higher fresh and dry herb yields/hectare, higher oil yield/hectare, maximum oil in linalool and minimum in estragole, and different pleasant flavors and colors than the local basil) by the following:

(I) Adding $48 \mathrm{~m}^{3} /$ hectare compost manure before planting.

(II) Cultivating the imported purple variety.

(III) Combination within adding $48 \mathrm{~m}^{3} /$ hectare compost and cultivating the purple variety.

\section{AUTHOR CONTRIBUTIONS}

All authors made substantial contributions to conception and design, acquisition of data, or analysis and interpretation of data; took part in drafting the article or revising it critically for important intellectual content; agreed to submit to the current journal; gave final approval of the version to be published; and agree to be accountable for all aspects of the work. All the authors are eligible to be an author as per the international committee of medical journal editors (ICMJE) requirements/guidelines.

\section{FUNDING}

There is no funding to report.

\section{CONFLICTS OF INTEREST}

The authors report no financial or any other conflicts of interest in this work.

\section{ETHICAL APPROVALS}

This study does not involve experiments on animals or human subjects.

\section{PUBLISHER'S NOTE}

This journal remains neutral with regard to jurisdictional claims in published institutional affiliation.

\section{REFERENCES}

1. Basil. Available via https://www.tridge.com/intelligences/basil/ export?q=Basil $\% 20$

2. Industrial Modernisation Centre (IMC). Herbs \& spices: global review, local assessment and SWOT analysis. 2006.

3. Toaima WIM, Hamed ES. Productivity evaluation of some imported basil varieties under Siwa Oasis conditions. Middle East J Agric 2016;5(4):810-9.

4. Joint FAO/WHO Food Standards Programme, Codex Committee on Spices and Culinary Herbs. Proposal for new work on codex standard for basil (revised proposal submitted by Egypt). 2017. Available via http://www.fao.org/fao-who-codexalimentarius/sh-proxy/ en/?lnk=1\&url=https $\% 253 \mathrm{~A} \% 252 \mathrm{~F} \% 252 \mathrm{Fworkspace}$.fao.org\% $\% 252 \mathrm{Fs}$ ites $\% 252 \mathrm{Fcodex} \% 252 \mathrm{FMeetings} \% 252 \mathrm{FCX}-736-03 \% 252 \mathrm{FReport} \% 2$ 52FFinal\%252520Report\%252FREP17_SCHe.pdf

5. Negm AM, Shareef N. Waste management in MENA regions. Springer, Cham, Switzerland, 2020.

6. Burpee Seeds Company. Available via https://www.burpee.com/

7. Gavrish Seeds Company. Available via http://gavrishseeds.ru/

8. SeDeK Seeds Company. Available via http://www.sedek.ru/

9. Whitman A, DeJohn S. Organic gardening for dummies. John Wiley \& Sons, Hoboken, NJ, 2009.

10. Leogrande R, Vitti C. Use of organic amendments to reclaim saline and sodic soils: a review. Arid Land Res Manage 2019;33(1):1-21.

11. Radovich TJ. The response of basil (Ocimum basilicum L.) to chicken manure, compost and urea applications. M.Sc. Thesis, University of Hawai`i, Honolulu, HI, 2000.

12. Anwar M, Patra DD, Chand S, Alpesh K, Naqvi AA, Khanuja SPS. Effect of organic manures and inorganic fertilizer on growth, herb and oil yield, nutrient accumulation, and oil quality of French basil Commun Soil Sci Plant Anal 2005;36:13-4.

13. Dobal S. Effect of organic manures on growth and yield of holy basil (Ocimum sanctum L.). M.Sc. Thesis, Uttarakhand University of Horticulture and Forestry, College of Horticulture, Bharsar Campus, V.C.S.G., Bharsar, India, 2016.

14. Wijaya VT, Teo SS. Evaluation of eggshell as organic fertilizer on sweet basil. Int J Sustainable Agric Res, Conscientia Beam 2019;6(2):79-86.

15. Pramod Mb, Uma J, Ravindra B, Siva V. Influence of organic manures and inorganic fertilizers on growth and yield parameters of sweet basil (Ocimum basilicum L.). Int J Chem Res 2020;8:4032-6.

16. Hiltunen R, Holm Y. Basil: the genus Ocimum. Harwood Academic Publishers, Reading, UK, 1999.

17. El-Ramady H, Alshaal T, Bakr N, Elbana T, Mohamed E, Belal A. The soils of Egypt. Springer, Cham, Switzerland, 2018.

18. Osman YAH, Abd El-Wahab MA. Production of medicinal and aromatic plants in New Lands. (In Arabic). Desert Research Center, Ministry of Agriculture, Cairo, Egypt, 2003

19. Basil: Upgrading the medicinal and aromatic plants value chain-access to export markets, Egypt. Available via https://rive.google.com/file/ d/175jAyk6_uWyHsJcKpWyzTw1Lkky9ZKkI/view (in Arabic).

20. Mohamed SM, Abou El-Ghait EM, El Shayeb NSA, Ghatas YA, Shahin AA. Effect of some fertilizers on improving growth and oil productivity of basil (Ocimum basilicum, L.) cv. Genovese plant. Egypt J Appl Sci 2015;30(6):384-99. 
21. Jackson ML. Soil chemical analysis. Constable. Co. Lt., London, UK, 1976.

22. AOAC. Association of Official Analytical Chemists. Official methods of analysis. AOAC International, Washington, DC, 2002.

23. Central Laboratory of Organic Agriculture (CLOA). Available via http://www.arc.sci.eg/instslabs/Default.aspx?OrgID=25\&Lang=en

24. Snedecor GW, Cochran WG. Statistical methods. The Iowa State Univ., Press, Ames, IA, 1982.

25. British Pharmacopoeia. Determination of volatile oil in drugs. The Pharmaceutical Press, London, UK, 1963.

26. Stenhagen E, Abrahamsson S, McLafferty FW. Registry of mass spectral data. Wiley \& Sons, New York, NY, 1974.

27. Massada Y. Analysis of essential oils by gas chromatography and mass spectrometry. Wiley \& Sons, New York, NY, 1976.

28. Jennings W, Shibamoto T. Qualitative analysis of flavor and fragrance volatiles by glass capillary gas chromatograph. Academic Press, New York, NY, 1980

29. National Committee for Clinical Laboratory Standards. Performance standards for antimicrobial susceptibility testing. Twelfth International Supplement, NCCS, Wayne, PA, 2002.

30. Adams RP. Identification of essential oil components by gas chromatography/quadrupole mass spectroscopy. Allured Publ., Carol Stream, IL, 2007.

31. Babushok VI, Linstrom PJ, Zenkevich IG. Retention indices for frequently reported compounds of plant essential oils. J Phys Chem Ref Data 2011;40(4):043101-47.

32. Abd El-Wahab MA. Effect of fertilization and irrigation on rosemary and geranium plants under Sinai conditions. Ph.D. Thesis, Fac. Agric., Tanta Univ., Tanta, Egypt, 2002.

33. Hasanuzzaman M, Fujita M, Oku H, Nahar K, Hawrylak-Nowak B. Plant nutrients and abiotic stress tolerance. Springer Nature Singapore Pte Ltd., Gateway, Singapore, 2018.

34. Mahmoud, Lobna Y. Using some organic components and organic fertilization for Ocimum basilicum, L. production. M.Sc. Thesis, Institute of Environmental Studies and Research, Ain Shams University, Cairo, Egypt, 2009.

35. Taie HAA, Salama ZA, Radwan, S. Potential activity of basil plants as a source of antioxidants and anticancer agents as affected by organic and bio-organic fertilization. Not Bot Horti Agrobot Cluj Napoca 2010;38(1):119-27.

36. El-Asbaily RMYA. Effect of organic and biofertilization on growth, yield and essential oil content of sweet basil (Ocimum basilicum). Ph.D. Thesis, Fac. Agric., Saba Basha, Alexandria Univ., Alexandria, Egypt, 2011.

37. Sirousmehr A, Arbabi J, Asgharipour MR. Effect of drought stress levels and organic manures on yield, essential oil content and some morphological characteristics of sweet basil (Ocimum basilicum). Adv Environ Biol 2014;8(4):880-5.

38. El-Naggar AHM, Hassan MRA, Shaban EH, Mohamed MEA. Effect of organic and biofertilizers on growth, oil yield and chemical composition of the essential oil of Ocimum basilicum L. plants. Alexandria J Agric Sci 2015;60(1):1-16.

39. Mohamed SM, Abou-El-Ghait EM, Mohamed YFY, El-Sabagh EGM. Integrated management of fertilizer (NPK, chicken manure and yeast) to improve the growth, oil productivity and the volatile oil constituents of Ocimum basilicum, L. var. genoves plant. Middle East J Agric Res 2017;6(4):1155-70.

40. Esmaielpour B, Rahmanian M, Heidarpour O, Shahriari MH. Effect of vermicompost and spent mushroom compost on the nutrient and essential oil composition of basil (Ocimum basilicum L.). J Essent Oil Bear Plants 2017;20(5):1283-92.

41. Phippen WB, Simon JE. Anthocyanins in basil (Ocimum basilicum L.). J Agric Food Chem 1998;46(5):1734-8.

42. Hochmuth RC, Davis LLL, Laughlin WL, Simonne EH. Evaluation of organic nutrient sources in the production of greenhouse hydroponic basil. North Florida Research and Education Center, Live Oak, FL, 2003. Research Report 2003-08.

43. Rahmanian M, Esmaielpour B, Hadian J, Shahriari M, Fatemi H. The effect of organic fertilizers on morphological traits, essential oil content and components of basil (Ocimum basilicum L.). J Agric Sci Sustainable Prod 2017;27(3):103-18.

44. El-Sheref GFH, Awadalla HA, Mohamed GA. Influence of organic manure, natural rocks and putrescine on yield and quality of sweet basil (Ocimum basilicum L.) grown in sand soil. J Soil Sci Agric Eng 2019;10(2):747-58.

45. Yaldız G, Çamlıca M, Özen F, Eratalar SA. Effect of poultry manure on yield and nutrient composition of sweet basil (Ocimum basilicum L.). Commun Soil Plant Anal 2019;50(7):838-52.

46. Simon JE, Morales MR, Phippen WB, Vieira RF, Hao Z. Basil: a source of aroma compounds and a popular culinary and ornamental herb. In: Janick J (ed.). Reprinted from: Perspectives on new crops and new uses, ASHS Press, Alexandria, VA, 1999.

47. Flanigan PM, Niemeyer ED. Effect of cultivar on phenolic levels, anthocyanin composition, and antioxidant properties in purple basil (Ocimum basilicum L.). Food Chem 2014;164:518-26.

48. Kovinich N, Kayanja G, Chanoca A, Otegui MS, Grotewold E. Abiotic stresses induce different localizations of anthocyanins in arabidopsis. Plant Signaling Behav 2015;10(7):e1027850.

49. Prinsi B, Morgutti S, Negrini N, Faoro F, Espen L. Insight into composition of bioactive phenolic compounds in leaves and flowers of green and purple basil. Plants 2020;9(1):2-16.

50. Labra M, Miele M, Ledda B, Grassi F, Mazzei M, Sala F. Morphological characterization, essential oil composition and DNA genotyping of Ocimum basilicum L. cultivars. Plant Sci 2004;167(4):725-31.

51. Landi M, Guidi L, Pardossi A, Tattini M, Gould KS. Photoprotection by foliar anthocyanins mitigates effects of boron toxicity in sweet basil (Ocimum basilicum). Planta 2014;240(5):941-53.

52. Stetsenko LA, Pashkovsky PP, Voloshin RA, Kreslavski VD, Kuznetsov VLV, Allakhverdiev SI. Role of anthocyanin and carotenoids in the adaptation of the photosynthetic apparatus of purple- and green-leaved cultivars of sweet basil (Ocimum basilicum) to high-intensity light. Photosynthetica 2020;58(4):890-901.

53. Serafini LA, Pauletti GF, Rota LD, Santos AC, Agostini F, Zattera F, et al. Evaluation of the essential oils from nine basil (Ocimum basilicum L.) cultivars planted in Southern Brazil. J Essent Oil Bear Plants 2009;12(4):471-5.

54. Ibrahim MM, Aboud KA, Al-Ansary AMF. Genetic variability among three sweet basil (Ocimum basilicum L.) varieties as revealed by morphological traits and RAPD markers. World Appl Sci J 2013;24(11):1411-9.

55. Wierdak RN. Morphological variability and essential oil composition of four Ocimum basilicum L. cultivars. J Essent Oil Bear Plants 2014;17(1):112-9.

56. Gupta S, Srivastava A, Shasany AK, Gupta AK. Genetics, cytogenetics, and genetic diversity in the genus Ocimum. In: Shasany A, Kole $\mathrm{C}$ (eds.). The Ocimum genome. Compendium of plant genomes, Springer, Cham, Switzerland, 2018.

57. Wierdak RN. Morphological and chemical variability of Ocimum basilicum L. (Lamiaceae). Mod Phytomorphol 2013;3:15-118.

58. Wierdak RN, Borowski B, Dzida K, Zawiślak G, Kowalski R. Essential oil composition of sweet basil cultivars as affected by nitrogen and potassium fertilization. Turk J Agric For 2013;37:427-36.

59. Pate RP, Kumar RR, Singh R, Singh RR, Rao BRR, Singh VR, et al. Study of genetic variability pattern and their possibility of exploitation in Ocimum germplasm. Ind Crops Prod 2015;66:119-22.

60. Said-Al Ahl HAH, Meawad AA, Abou-Zeid EN, Ali MS. Evaluation of volatile oil and its chemical constituents of some basil varieties in Egypt. Int J Plant Res 2015;1(3):103-6.

61. Rawat R, Negi KS, Mehta PS, Tiwari V, Verma SK, Bisht IS. Study of six varieties of sweet basil (Ocimum basilicum L.) and their morphological variations. J Non Timber For Prod 2016;23(1):1-4. 
62. El-Ziat RA, Swaefy HM, Esmail SEA. The response of red rubin basil plant to organic fertilizer and humic acid versus chemical fertilizers. Middle East J Agric Res 2018;7(3):740-51.

63. Kamatou GPP, Viljoen AM. Linalool - a review of a biologically active compound of commercial importance. Nat Prod Commun 2008;3(7):1183-92.

64. Badr SEA, Sakr DM, Mahfouz SA, Abdelfattah MS. Licorice (Glycyrrhiza glabra L.): Chemical composition and biological impacts. Res J Pharm Biol Chem Sci 2013;4(3):606-21.

65. Farag MA, Abdelfattah MS, Badr SEA, Wessjohann LA. Profiling the chemical content of Ficus lyrata extracts via UPLC-PDA-qTOF-MS and chemometrics. Nat Prod Res 2014;28(19):1549-56.

66. Elnagar EEM. Effect of chemical fertilization and some stimulators on lemongrass under Siwa Oasis conditions. M.Sc. Thesis, Fac. Agric. (Saba Basha), Alexandria Univ., Alexandria, Egypt, 2019.

67. Abdelfattah MS, Badr SEA, Lotfy SA, Attia GH, Aref AM, Abdel Moneim AE, et al. Rutin and selenium co-administration reverse 3-nitropropionic acid-induced neurochemical and molecular impairments in a mouse model of Huntington's disease. Neurotoxic Res 2020;37(1):77-92.

68. European Medicines Agency. Committee on herbal medicinal products, 2005. Available via http://www.ema.europa.eu/docs/en_GB/ document library/Scientific guideline/2010/04/WC500089960.pdf

69. BASIL. Available via https://www.rxlist.com/basil/supplements.htm

70. International Trade Center. Essential oils and oleoresins, market insider. Geneva, Switzerland, 2014. Available via https://www. intracen.org/itc/market-insider/essential-oils/

71. Guenther E. The essential oils. D. Van Nostrand Co., Inc., New York, NY, vol. III, 1961.
72. Peter KV. Handbook of herbs and spices. 2nd edition, Woodhead Publishing Limited, Sawston, Cambridge, vol. 1., 2012.

73. Nofal EMS, Menesi FAE. Volatile oils and its plants. Academic Bookshop Co., Giza, Egypt, 2019. (in Arabic).

74. Ličina VD, Jelačić SĆ, Beatović DV, Mladenović SBA. Mineral composition of different basil (Ocimum spp.) genotypes. Hem Ind 2014;68(4):501-10.

75. Beatović D, Milošević DK, Trifunović S, Šiljegović J, Glamočlija J, Ristić M, et al. Chemical composition, antioxidant and antimicrobia activities of the essential oils of twelve Ocimum basilicum L. cultivars grown in Serbia. Rec Nat Prod 2015;9(1):62-75.

76. Basil varieties: 15 types of basil to add a little spice in your herb garden. Available via https://howtoculinaryherbgarden.com/types-ofbasil/

77. Purple basil: a clove-like, slightly spicy flavor. Available via https:// superbherb.co.nz/product/purple-basil/

\section{How to cite this article:}

Toaima WIM, Badawy MYMA, Hamed ES. Effect of organic fertilization on productivity of some newly introduced basil varieties under Siwa Oasis conditions. J Appl Biol Biotech 2022; 10(02):74-88. 